\author{
Pedagogy Journal of English Language Teaching \\ Volume 8, Number 2, June 2020 \\ e-ISSN: 2580-1473; p-ISSN: 2338-882X \\ Published by Institut Agama Islam Negeri Metro \\ DOI: 10.32332/pedagogy.v8i1. 2069
}

\title{
Exploring Creativity in English Writing by Using Instagram: University Students Perceptions
}

\author{
Kamal Yusuf $^{*}$, Nikmatul Jazilah ${ }^{2}$ \\ Universitas Islam Negeri (UIN) Sunan Ampel Surabaya, Indonesia ${ }^{1,2}$ \\ Email: kamalinev@gmail.com ${ }^{1}$ * \\ Email: nikmatuljazilaah@gmail.com²
}

\begin{abstract}
Instagram is one of the social media platforms that used as a media for educational purposes. This study aimed at investigating university students' perceptions of using Instagram as an online platform to explore their creativity in English writing skill. The study used a quantitative research design. The participants of this study were students of the English Education Department of Universitas Islam Negeri Surabaya, who took a Writing English course and used Instagram in their learning activity. The questionnaire was used to collect data of this present research in the form of five-point Likert scale statements that expressed in strongly agree, agree, neutral, disagree, and strongly disagree. The descriptive quantitative were conducted on the data of analyzing the students' perceptions of using Instagram to know their responses. The findings indicated that the students demonstrated positive perceptions in using Instagram to interact with their lecture and classmates on Instagram to improve their English writing ability. The result of this research can inform that the use of Instagram in teaching writing can also shape them to become more creative and enjoyable in English writing learning.
\end{abstract}

Keywords: Creativity, English learning, English writing skill, Instagram, Technology.

\section{INTRODUCTION}

Nowadays, the development of technology brings a significant impact on the social life of the society. Technology becomes a tool to make someone easy to express their opinion, feeling, and thought. In this era, the use of technology increases in various aspects. One of the technologies that often used by people's life is social media. This social media is useful for someone's life both for communicating with others or gaining the information. We can interact with our families or friends using social media. Definition of social media refers to various internet and cellular-based services that the users can allow and participate in online exchanges, contribute content, or join online communities (Dewing, 2012, p. 1). 
In social media, there are many applications like WhatsApp, Facebook, Line, Instagram, etc. The use of social media has started to spread in various aspects, including education. Social media is used as a tool in the web-based teaching and learning process. Since social media was introduced, it has been an appliance and integrating for learning plans in many ways (Gikas \& Grant, 2013; J Mao, 2014).

Instagram is one of the online applications that make its users unable to take pictures or videos and share them publicly or privately spheres. This social media is still the most popular application for teenagers. Recent evidence suggests that students' attitudes using social media for sharing pictures and videos become the features of Instagram (Mao, 2014). Furthermore, Mansor \& Rahim (2017) stated that using online interaction such as Instagram had inspired students' interest in learning English language activity. Instagram has a positive interaction when the students can read and write their postings. By far, the teacher chooses Instagram as a tool to develop creative activity in the English learning process. One of the activities that can be implemented by using Instagram in teaching writing by using the features provided on Instagram. This strategy can attract student's attention in English writing by utilizing Instagram. As a result, this study aimed to investigate students' perceptions of Instagram as an English language learning platform and how this application can help students to explore their creativity in English writing captions.

Numerous studies have been conducted concerning the use of Instagram to increase students writing skills. Selected studies will be presented as follows. The study was conducted by (Zidny, 2017); his research was to determine the improvements in students writing skills and find the solutions to make students interested in learning writing skills by using Instagram for learning English. Thus, the researcher gives some suggestions to the teachers to know the students' interests in students' activities that post on Instagram. Besides, the teachers can motivate the students to write and make writing as their habit on Instagram.

Another study was conducted by Anggraeni (2017). She explained students' perspectives toward the use of Instagram in writing class. Her finding shows that students find the benefits of using Instagram in their writing class, like improve their writing skills, their confidence to publish their written, not time-consuming, easy to do assignments anytime and everywhere, getting comments and feedback. The students also find the barriers concerning the use of Instagram, i.e., for example, are the signal or internet access and making grammar mistakes.

Mansor \& Rahim (2017) in their study, revealed the students experience in using Instagram as a tool to make students being more motivated and to enhance their interest in participating in the learning process using Instagram. Furthermore, their finding shows that the students are motivated to develop their online communication and build their confidence in giving feedback on their assignments to another.

Another research was conducted by AlAli (Al-Ali, 2014). In their paper which focuses on the integrated of Instagram as a production learning tool in creative writing mentioned that the students are active to select pictures and formulate their ideas and creativity in their writing task. Moreover, he said that writing captions on Instagram are recommended to make students easy to share their ideas and make them be motivated to do the task on Instagram.

Writing is one of the skills in language learning that should be mastered by students. According to Rivers (Rivers, 1981, p. 294), writing is conveying original information or expressions ideas sequentially in new languages. Furthermore, Meyer (2005) affirms that writing is an action-a process of discovering and 
organizing your ideas, putting them on paper, and reshaping and revising them. Furthermore, Wati (2019) defines that writing has activity in writing and formulating some ideas to create meaning on paper. In short, the definition of writing is the process of creating and generating ideas to communicate with others on the paper or screen.

Teaching writing is one of the essential skills that educators teach to their students. According to Harmer (2001, p. 25), there are two approaches to teaching writing. The first approach is to focus on the product of the writing process. The second approach is focused on the writing process itself. He additionally stated that if the focus is on the writing process, it will guide in the process approach in writing. However, the teacher has to pay attention to the process of writing so the students can write and produce well-written text.

The caption is a text written made by someone to express their ideas about the photos that they shared on Instagram. Grayam (2010) stated that caption is a short description in which accompanies the illustration and gives the important details of a photograph. On Instagram, students are able to upload photos or videos, then giving the caption based on the pictures and videos. The other students can provide likes or comments or asking something according to the description of the caption. It will make good interaction between the students (D. Gunantar \& Transinata, 2019). In this situation, the benefit of Instagram in the learning activity is to increase students' English writing skills. They will be inspired by the picture that they will upload to think and arrange a good text to write a caption on the caption box and write it clearly and deliver the message briefly. By utilizing this social media, teachers need to contextualize the usage to make equal of students need and learning abilities as well as the set of the curriculum (Delello et al., 2015).

Despite various research, the authors identified several aspects that were not under investigation. Although some studies based on the use of Instagram, a qualitative one to explain, is worthy of mention how the learners experienced English learning using Instagram, particularly those in the EFL sense. It will offer a detailed understanding of how Instagram help learners create their language awareness to write creatively. Research that pays attention to the perspectives of departmental English students can bring fruitful results because English is an inseparable part of their language learning everyday lives and their needs that could lead to wealthy discovery.

As far as we concerned, there have been no previous studies concerning university students' perception, especially those are based on Islamic higher education related to the use of Instagram as a tool for their creativity in English writing. Considering the gaps, this present paper, therefore, was aimed to explore university student's responses to using Instagram in their English teaching-learning process at Universitas Islam Negeri Sunan Ampel Surabaya. The foci of the study are formulated into the following research questions:

1. Do students of Pendidikan Bahasa Inggris (PBI) Universitas Islam Negeri Sunan Ampel explore their creativity in English writing learning activity using Instagram?

2. What are PBI Universitas Islam Negeri Sunan Ampel students' perceptions on the use of Instagram in English writing learning activity?

\section{METHOD}

We applied the descriptive qualitative method in the present research as it explored the thoughts, opinions and perspectives of the participants (Creswell, 2002). Therefore, through the descriptive qualitative method, participants' experiences and perceptions towards the use of Instagram to creatively writing in English learning can be comprehensively elaborated.

The present study employed an instrument on students' perceptions of using 
Instagram in their English learning activity to enhance creativity in English writing skills. The instrument used was a questionnaire to reveal their perceptions that were adapted from Handayani et al. (2018) with some necessary modifications. There were sixteen item statements of the questionnaire that were divided into three parts, i.e., part one is about students' writing competence, part two asks students' interest, and part three deals with the learning process. All the items were put into a five-point Likert scale ranging from Strongly Agree (SA) to Strongly Disagree (SD). The positive statements were given scores in a sequence of $5,4,3,2$, and 1 , while the negative item statements were set the opposite scores (Oppenheim, 2001). The positive statements respectively were scored: Strongly Agree was weighted 5, Agree was weighted 4, Neutral was weighted 3, Disagree was weighted 2, and Strongly Disagree was weighted 1. Successively for the negative statements were weighted the opposite: Strongly Disagree was weighted 5, Disagree was weighted 4 , Neutral was weighted
3, Agree was weighted 2, and Strongly Agree was weighted 1 .

Thirty students of PBI at UIN Sunan Ampel Surabaya participated in this study. They undertook the Written English course. In the Written English course, the students have to make an argumentative essay and then upload their essays on Instagram. While they upload their essays, they have to use hashtags (\#) that have been determined before by the teacher. Other students, therefore, can find their colleague's writing tasks and then they are able to give feedback or comments in their classmate's comment box. This study seeks to provide a description and analysis of the usage of Instagram in language learning classes.

\section{RESULT AND DISCUSSION}

Result

This study used a questionnaire to identify students' responses. The questionnaire was divided into three parts. The following part is a description of the research findings of each part of the questionnaire.

Table 1. Students' perception in the using of Instagram to explore their creativity in English writing skill

\begin{tabular}{|c|c|c|c|c|c|c|c|}
\hline \multirow[b]{2}{*}{ No } & \multicolumn{6}{|c|}{ PART 1: Writing Competence } & \multirow[b]{2}{*}{ Total $n$} \\
\hline & Statement & SA & A & $\mathrm{N}$ & $\mathrm{D}$ & SD & \\
\hline 1. & I can do well in my English writing class. & 2 & 11 & 16 & - & 1 & 30 \\
\hline 2. & $\begin{array}{l}\text { I am confident about my ability to } \\
\text { compose an opinion essay on the writing } \\
\text { test. }\end{array}$ & 1 & 14 & 14 & - & 1 & 30 \\
\hline 3. & $\begin{array}{l}\text { I can convey ideas based on the given } \\
\text { topic properly. }\end{array}$ & 2 & 12 & 15 & 1 & - & 30 \\
\hline 4. & $\begin{array}{l}\text { I can organize ideas based on the given } \\
\text { topic in each paragraph coherently. }\end{array}$ & 2 & 10 & 17 & 1 & - & 30 \\
\hline 5. & $\begin{array}{l}\text { I can use proper vocabulary to the given } \\
\text { topics appropriately. }\end{array}$ & 2 & 19 & 8 & - & 1 & 30 \\
\hline 6. & $\begin{array}{l}\text { I can apply correct grammar in delivering } \\
\text { ideas based on the given topic suitably. }\end{array}$ & - & 6 & 22 & 2 & 1 & 30 \\
\hline \multirow[t]{3}{*}{7.} & $\begin{array}{l}\text { I can use appropriate spelling, } \\
\text { punctuation, and capitalization in } \\
\text { expressing ideas based on the given topic } \\
\text { correctly. }\end{array}$ & - & 15 & 14 & 1 & - & 30 \\
\hline & Total Score & 45 & 348 & 318 & 10 & 4 & \\
\hline & Percentage & $5 \%$ & $41 \%$ & $50 \%$ & $2 \%$ & $2 \%$ & $100 \%$ \\
\hline
\end{tabular}


Notes:

SA: Strongly agree
A: Agree
$\mathrm{N}$ : Neutral
D: Disagree

SD: Strongly disagree

Table 1 shows the scores and percentages of questionnaire items from part one. There were $5 \%$ of students who started strongly agree on using Instagram to improve their writing competence. Besides, there were $41 \%$ of students ranked agree. Most of the students $(50 \%)$ stated their neutrality in learning writing skills using Instagram. Two per cent of students think that learning English writing skills of using Instagram cannot engage and motivated them in learning. The last result was strongly disagreed, with just $2 \%$ of students expressed their responses. In conclusion, the total scores of students' perception of the use of Instagram to explore creativity in writing skills were $46 \%$. This result means that the students, in general, agreed on using Instagram to explore their creativity in English writing skills, especially for enhancing their writing competence.

Table 2. Students' interest in the using of Instagram to explore their creativity in writing skill

\begin{tabular}{|c|c|c|c|c|c|c|c|}
\hline \multirow[b]{2}{*}{ No } & \multicolumn{6}{|c|}{ PART 2: Interest } & \multirow[b]{2}{*}{ Total $n$} \\
\hline & Statement & SA & A & $\mathrm{N}$ & $\mathrm{D}$ & SD & \\
\hline 8. & It is fun to post writing assignments on Instagram. & 13 & 13 & 2 & 1 & 1 & 30 \\
\hline 9. & $\begin{array}{l}\text { It is interesting to give feedback through } \\
\text { Instagram. }\end{array}$ & 9 & 16 & 2 & 2 & 1 & 30 \\
\hline 10. & It is interesting to get feedback through Instagram. & 9 & 12 & 5 & 3 & 1 & 30 \\
\hline \multirow[t]{3}{*}{11.} & $\begin{array}{l}\text { Posting writing assignments on Instagram } \\
\text { motivates me to write better. }\end{array}$ & 14 & 8 & 7 & 2 & - & 30 \\
\hline & Total & 225 & 196 & 62 & 16 & 3 & \\
\hline & Percentage & $37 \%$ & $\begin{array}{l}41 \\
\%\end{array}$ & $17 \%$ & $6 \%$ & $2 \%$ & $100 \%$ \\
\hline
\end{tabular}

Notes:

SA: Strongly agree
A: Agree
$\mathrm{N}$ : Neutral
D: Disagree
SD: Strongly disagree

Table 2 of part two showed the scores and percentages of questionnaire items. $37 \%$ of students stated strongly agree, i.e., those interested in using Instagram in teaching writing. Then, the following result was $41 \%$ of students who agreed to use Instagram. The next was students' demonstrated neutrality, with $17 \%$ of them, and those who disagreed were about $6 \%$. The last result was strongly disagreed, with just $2 \%$ of students stated their responses. In conclusion, the total scores of students' interest in the use of Instagram to explore creativity in writing skills were $78 \%$. It indicated that the students were strongly agreed and had a high interest in using Instagram to explore their creativity in writing skills.

Table 3. Students' perception of the process of learning in the using of Instagram to explore their creativity in writing skill

\begin{tabular}{clcccccc}
\hline & \multicolumn{3}{c}{ PART 3: Process of Learning } & & \\
\cline { 2 - 7 } No & \multicolumn{1}{c}{ Statement } & SA & A & N & D & SD & Total n \\
\hline 12. & $\begin{array}{l}\text { Notes posted by the teacher on Instagram help me to } \\
\text { understand the material better. }\end{array}$ & 8 & 7 & 13 & 1 & 1 & 30
\end{tabular}




\begin{tabular}{|c|c|c|c|c|c|c|c|}
\hline 13. & $\begin{array}{l}\text { Pictures and a video about certain topics posted by } \\
\text { the teacher on Instagram encourage me to make } \\
\text { opinions }\end{array}$ & 4 & 17 & 9 & - & - & 30 \\
\hline 14. & $\begin{array}{l}\text { I enjoy giving feedback/corrections to my partner's } \\
\text { outline posted on Instagram. }\end{array}$ & 6 & 10 & 10 & 2 & 2 & 30 \\
\hline 15 . & $\begin{array}{l}\text { My friends' feedback helps me in making my outline } \\
\text { better. }\end{array}$ & 11 & 12 & 7 & - & - & 30 \\
\hline \multirow[t]{3}{*}{16.} & The features available on Instagram (DM and & 5 & 14 & 8 & 1 & 2 & 30 \\
\hline & Total & 170 & 240 & 141 & 8 & 5 & \\
\hline & Percentage & $22 \%$ & $40 \%$ & $31 \%$ & $3 \%$ & $4 \%$ & $100 \%$ \\
\hline
\end{tabular}

Notes:

SA: Strongly agree
A: Agree
$\mathrm{N}$ : Neutral
D: Disagree
SD: Strongly disagree

The next description of the scores and percentages for questionnaire items of part three is provided in Table $3.22 \%$ of students ranked strongly agree and confirmed their perceptions on the process of learning in using Instagram in teaching writing. Then, $40 \%$ of students stated their agreement with the statements. The following were students' neutral responses, with $31 \%$ of them. The last finding was $3 \%$ of students were ranked disagree, and just $2 \%$ of students strongly disagreed with the process of learning in using Instagram in teaching writing. All in all, the total scores of students' perception in the process of learning in using of Instagram to explore creativity in the process of learning writing skills were $62 \%$. This number signified that the students were agreed and they showed their positive response toward using Instagram to explore their creativity in writing skill. They also feel motivated and enjoyed the process of learning using Instagram.

\section{Discussion}

Overall, there seems to be some evidence to indicate that Instagram is a social media that can help the students to express their idea and creativity in language skill (Erarslan, 2019; Sari
\& Wahyudin, 2019; Gonulal, 2019). Besides, most students use Instagram as the popular social media with writing skills to describe pictures that uploaded in their Instagram (Prasetyawati \& Ardi, n.d.). Hence, the discussion of this study was based on the result of the finding of using Instagram as social media platforms. It was aimed to fulfil the gap in the literature and to use Instagram for language learning purpose.

Furthermore, most of the students think positively about using Instagram in the teachinglearning process. It can be seen from the findings aforementioned, with the total percentages showed that they agree and feel interested in interacting with their teacher and colleagues, such as giving feedback when using Instagram. Moreover, they have positive perspective of using Instagram in their English writing creativity (Candradewi Wahyu Anggraeni, 2017).

The students of PBI UINSA who took Writing English course have participated in the learning activities using Instagram. They feel more motivated to write and share their ideas with their colleagues on Instagram. They also get experience to have learning activity outside the classroom. The students can write the tasks given by lecture that used Instagram by sharing their postings, pictures and captions descriptions (D. A. Gunantar \& Transinata, 2019). Then they have to provide a hashtag (\#) to make the lecture and the other college students are easy to trace what they already posted. 
There are many benefits to using Instagram to learn English writing skill. Based on the questionnaire items, the students stated that using Instagram can enhance their learning activity, such as making their written competence to be better and improved. This is in line with what has been done by Shazali et al. (2019) in their study. Another advantage students confirmed was the activity can make them more interest and enjoy the process of learning English writing. They feel more confident to compose their ideas, organize it based on the topics properly. Moreover, writing using Instagram can make them be motivated to write better because they can get feedback from others.

In addition, the findings demonstrated that students who give feedback to each other could help the writing outline be better. They can utilize the comments box to provide feedback. The lecture also can give some notes to help the students more understand the material. This indicates that the interaction between students and students or between students and lecturer is in proper ways. They can take a positive way in the utilization of this online platform.

\section{CONCLUSION}

The findings of this study argued that the students have a positive response to an online learning platform using Instagram to explore their creativity in English writing skill. It can be seen from their responses. They could utilize many features on Instagram in English writing then get feedback to others or give others feedback about their writing. The feedbacks are of different types such as on the grammar, vocabulary, the outline of the essay, the ideas, etc. Students were very interactive to give and respond to feedback of the others. They also learnt from their mistakes. The students who participated in this study used Instagram that could encourage them to interact with the lecturer and also their friends outside the classroom. In addition, the students confirmed that using Instagram made them could express their ideas and opinion. In conclusion, Instagram for English writing can be a useful tool in the learning activity, and it can be an interesting tool for the students to learn and enjoy the process of English learning.

\section{REFERENCES}

Al-Ali, S. (2014). Embracing the Selfie Craze: Exploring the Possible Use of Instagram as a Language mLearning Tool. Issues and Trends in Educational Technology, 2(2), 1-16. https://doi.org/10.2458/azu_itet_v2i2_aiali

Anggraeni, C. W. (2017). Students' Perspectives toward the Use of Instagram. 1st English Language and Literature International Conference (ELLic).

Anggraeni, Candradewi Wahyu. (2017). STUDENTS' PERSPECTIVES TOWARD THE USE OF INSTAGRAM IN WRITING CLASS. 7.

Creswell, J. W. (2002). Educational Research: Planning, Conducting, and Evaluating Quantitative. Prentice Hall.

Delello, J., McWhorter, R. R., \& Camp, K. M. (2015). Using Social Media as a Tool for Learning: A Multi-Disciplinary Study. $14,163-180$.

Dewing, M. (2012). Social Media: An Introduction. Library of Parliament.

Erarslan, A. (2019). Instagram as an Education Platform for EFL Learners. The Turkish Online Journal of Educational Technology, 18(3), 16.

Gikas, J., \& Grant, M. M. (2013). Mobile Computing Devices in Higher 
Education: Student Perspectives on Learning with Cellphones, Smartphones \& Social Media. The Internet and Higher Education, $19,18-26$. https://doi.org/https//doi.org/10.1016/j.ih educ.2013.06.002

Gonulal, T. (2019). The Use of Instagram as a Mobile-Assisted Language Learning Tool. Contemporary Educational Technology, 10(3). https://doi.org/10.30935/cet.590108

Grayam, L. (2010). Writing Photo Captions, Redbubble Artistic Journal. https://www.redbubble.com/people/gray am/journal/4742583writing-photocaptions

Gunantar, D. A., \& Transinata, T. (2019). Writing Caption on Instagram as Media for Student's Motivation and Writing Skill Improvement. ETERNAL (English Teaching Journal), 10(1), 6.

Gunantar, D., \& Transinata, T. (2019). Writing Caption on Instagram as Media for Student's Motivation and Writing Skill Improvement. $\quad 10(1), \quad 30-35$. https://doi.org/DOI: 10.26877/eternal.v10i1.3905

Handayani, A. D., Cahyono, B. Y., \& Widiati, U. (2018). The Use of Instagram in the Teaching of EFL Writing: Effect on Writing Ability and Students' Perceptions. Studies in English Language Teaching, 6(2), 112. https://doi.org/10.22158/selt.v6n2p112

Harmer, J. (2001). The Practice of English Language Teaching. Pearson Education Limited.
Mansor, N., \& Rahim, N. A. (2017). Instagram in ESL Classroom. Man in India, 97(2), 107-114. https://doi.org/2017

Mao, J. (2014). Social Media for Learning: A Mixed Methods Study on High School Students' Technology Affordances and Perspectives. Computer Human Behaviour, 33, 213-223. https://doi.org/10.1016/j.chb.2014.01.00 2

Mao, Jin. (2014). Social media for learning: A mixed methods study on high school students' technology affordances and perspectives. Computers in Human Behavior, 33, 213-223. https://doi.org/10.1016/j.chb.2014.01.00 2

Meyer, H. (2005). Analyzing argumentative writing. English in Education, 39(3), 78 92. https://doi.org/10.1111/j.17548845.2005.tb00626.x

Oppenheim, A. N. (2001). Questionnaire Design, Interviewing and Attitude Measurement. Continuum.

Prasetyawati, O. A., \& Ardi, P. (n.d.). INTEGRATING INSTAGRAM INTO EFL WRITING TO FOSTER STUDENT ENGAGEMENT. 23.

Rivers, W. M. (1981). Teaching Foreign Language Skill. The University of Chicago.

Sari, F. M., \& Wahyudin, A. Y. (2019). UNDERGRADUATE STUDENTS' PERCEPTIONS TOWARD BLENDED LEARNING THROUGH INSTAGRAM IN ENGLISH FOR BUSINESS CLASS. International Journal of Language Education, $1(1)$, 64. https://doi.org/10.26858/ijole.v1i1.7064 
Shazali, S. S., Shamsudin, Z. H., \& Yunus, M. Md. (2019). Instagram: A Platform to Develop Student's Writing Ability. International Journal of Academic Research in Business and Social Sciences, 9(1), Pages 88-98. https://doi.org/10.6007/IJARBSS/v9i1/5365

Wati, N. S. (2019). The Effect Of Creativity Toward Students' Achievement in Writing Ability. Pedagogy: Journal of English Language Teaching, 6(2), 141. https://doi.org/10.32332/pedagogy.v6i2. 1330

Zidny, I. (2017). Improving Students' Writing Skill Using Instagram in Grade $\mathrm{X}$ of Science 5 at SMAN5 Yogyakarta. English Language Teaching Journal, 6(4), 188-195. 